\title{
The Postmodern Infantilization of the Media
}

\author{
Jacopo Bernardini
}

Contemporary societies are experiencing a new phenomenon, for which children and teenagers represent the epicenter of consumer culture, influencing the media system and giving shape to the desires and behaviors of a growing number of adults. The press has coined several labels - e.g., kidults, adult-children, and adultescents - to describe an increasingly recurrent reality. Husbands in their forties spend hours playing the same video games that obsess adolescents; managers and politicians behave like impulsive teenagers; and young adults live with their parents, watch cartoons and see in marriage and in parenting an obstacle to their independence. In general, one finds infantile adults, unable to grow up and take responsibilities.

The social sciences, in recent times, are taking an interest in the phenomenon, comparing it, mostly, to the socioeconomic changes that have characterized the postmodernity (Schor 2004; Barber 2007; Blatterer 2007) or to historical-generational perspectives (Mitchell 2006; Cross 2008; Bonazzi and Pusceddu 2008), eluding, however, a fundamental sector: the fruition of media and new technologies.

There are, in fact, many clues reflecting the systematic increase of the infantilist influence in major mass-media areas. The television schedule, for instance, has gradually lost its original pedagogic and cultural depth in favor of fun and entertainment. The movie industry increasingly markets kidult movies, sequels, remakes, and the heroes of comics and cartoons at the expense of the complexity of plot and dialogue. The use of the Internet by adults seems to be increasingly linked to recreational motivations, while that of video games has acquired a nostalgic-escapist function that promotes the regression of the adult male to a utopian world of fantasy and masculinity, resulting in an escape from family obligations and social responsibilities.

These are the four areas where the media promotion of the contemporary infantilist culture is most evident; thereby, they will be analyzed.

Compared to a mainly pedagogical origin and to a past characterized by a wide cultural value, television schedules today are dominated by reality shows, pseudo-documentaries with veiled educational appearances intended to shock and amuse the viewer, and talk shows that constantly encourage protagonists to fight, scream and behave like spoiled children.

Table 1 shows the worldwide highest rated TV shows of the last ten years. We can see that $45 \%$ of the most watched programs are television series (mostly medical drama and police dramas like CSI or NCIS), $41 \%$ are talent and reality shows, $7 \%$ sitcoms and 7\% sports programs. Reality shows have been hugely successful in the past decade, in particular, Dancing with the Stars and American Idol. Dancing with the Stars is present 13 times in our table, American Idol 16 times. The latter is, undoubtedly, the most successful program of the decade, so much so that it ranks in the first place for six consecutive seasons, from 2003-2004 to 2008-2009, and again in 2010-2011. American Idol is a program that puts the life of some teenager in an American singing school on display: first loves, dreams, quarrels. Apparently addressed to peers of the protagonists, it has found unexpected success with adult audiences, especially among parents who began watching the program with their children and ended up deeply involved and childishly identified with the teenager. 
Table 1. Most watched TV shows worldwide

\begin{tabular}{|c|c|c|c|c|c|c|c|c|c|}
\hline & 2003-4 & 2004-5 & 2005-6 & 2006-7 & 2007-8 & 2008-9 & 2009-10 & 2010-11 & 2011-12 \\
\hline 1 & $\begin{array}{l}\text { American } \\
\text { Idol }\end{array}$ & $\begin{array}{l}\text { American } \\
\text { Idol }\end{array}$ & $\begin{array}{l}\text { American } \\
\text { Idol }\end{array}$ & $\begin{array}{l}\text { American } \\
\text { Idol Results }\end{array}$ & $\begin{array}{l}\text { American } \\
\text { Idol }\end{array}$ & $\begin{array}{l}\text { American } \\
\text { Idol Results }\end{array}$ & N.C.I.S. & $\begin{array}{l}\text { American } \\
\text { Idol }\end{array}$ & $\begin{array}{l}\text { Sunday } \\
\text { Night } \\
\text { Football }\end{array}$ \\
\hline 2 & C.S.I. & C.S.I. & $\begin{array}{l}\text { American } \\
\text { Idol } \\
\text { Results }\end{array}$ & $\begin{array}{l}\text { American } \\
\text { Idol }\end{array}$ & $\begin{array}{l}\text { American } \\
\text { Idol Results }\end{array}$ & $\begin{array}{l}\text { American } \\
\text { Idol }\end{array}$ & $\begin{array}{l}\text { Sunday } \\
\text { Night } \\
\text { Football }\end{array}$ & $\begin{array}{l}\text { American } \\
\text { Idol } \\
\text { Results }\end{array}$ & $\begin{array}{l}\text { American } \\
\text { Idol } \\
\text { Results }\end{array}$ \\
\hline 3 & $\begin{array}{l}\text { American } \\
\text { Idol results }\end{array}$ & $\begin{array}{l}\text { American } \\
\text { Idol results }\end{array}$ & C.S.I. & $\begin{array}{l}\text { Dancing } \\
\text { with Stars }\end{array}$ & $\begin{array}{l}\text { Dancing } \\
\text { with Stars }\end{array}$ & $\begin{array}{l}\text { Dancing } \\
\text { with Stars }\end{array}$ & $\begin{array}{l}\text { Dancing } \\
\text { with Stars }\end{array}$ & $\begin{array}{l}\text { Sunday } \\
\text { Night } \\
\text { Football }\end{array}$ & N.C.I.S. \\
\hline 4 & $\begin{array}{l}\text { Survivor: } \\
\text { all stars }\end{array}$ & $\begin{array}{l}\text { Desperate } \\
\text { House } \\
\text { Wives }\end{array}$ & $\begin{array}{l}\text { Desperate } \\
\text { House } \\
\text { Wives }\end{array}$ & C.S.I. & $\begin{array}{l}\text { Dancing } \\
\text { with Stars } \\
\text { res. }\end{array}$ & C.S.I. & $\begin{array}{l}\text { The } \\
\text { Mentalist }\end{array}$ & $\begin{array}{l}\text { Dancing } \\
\text { with Stars }\end{array}$ & $\begin{array}{l}\text { American } \\
\text { Idol }\end{array}$ \\
\hline 5 & Friends & $\begin{array}{l}\text { Survivor: } \\
\text { Palau }\end{array}$ & $\begin{array}{l}\text { Grey's } \\
\text { anathomy }\end{array}$ & $\begin{array}{l}\text { Dancing } \\
\text { with Stars } \\
\text { res. }\end{array}$ & $\begin{array}{l}\text { Desperate } \\
\text { Housewives }\end{array}$ & N.C.I.S. & $\begin{array}{l}\text { N.C.I.S.: } \\
\text { Los } \\
\text { Angeles }\end{array}$ & N.C.I.S. & $\begin{array}{l}\text { Dancing } \\
\text { with Stars }\end{array}$ \\
\hline 6 & $\begin{array}{l}\text { Survivor: } \\
\text { Pearl Island }\end{array}$ & $\begin{array}{l}\text { Survivor: } \\
\text { Vanuatu }\end{array}$ & $\begin{array}{l}\text { Without a } \\
\text { Trace }\end{array}$ & $\begin{array}{l}\text { Grey's } \\
\text { Anathomy }\end{array}$ & House & $\begin{array}{l}\text { The } \\
\text { Mentalist }\end{array}$ & C.S.I. & $\begin{array}{l}\text { Dancing } \\
\text { with stars } \\
\text { res. }\end{array}$ & $\begin{array}{l}\text { N.C.I.S.: } \\
\text { Los } \\
\text { Angeles }\end{array}$ \\
\hline 7 & $\begin{array}{l}\text { The } \\
\text { Apprentice }\end{array}$ & $\begin{array}{l}\text { C.S.I.: } \\
\text { Miami }\end{array}$ & $\begin{array}{l}\text { Dancing } \\
\text { with stars }\end{array}$ & House & C.S.I. & $\begin{array}{l}\text { Dancing } \\
\text { with Stars } \\
\text { res. }\end{array}$ & $\begin{array}{l}\text { Dancing } \\
\text { with stars } \\
\text { res. }\end{array}$ & $\begin{array}{l}\text { N.C.I.S.: } \\
\text { Los } \\
\text { Angeles }\end{array}$ & $\begin{array}{l}\text { Dancing } \\
\text { with Stars } \\
\text { res. }\end{array}$ \\
\hline 8 & E.R. & $\begin{array}{l}\text { Without a } \\
\text { Trace }\end{array}$ & $\begin{array}{l}\text { Survivor: } \\
\text { Guatemala }\end{array}$ & $\begin{array}{l}\text { Sunday } \\
\text { Night } \\
\text { Football }\end{array}$ & $\begin{array}{l}\text { Gray's } \\
\text { Anathomy }\end{array}$ & $\begin{array}{l}\text { Sunday } \\
\text { Night } \\
\text { Nootball }\end{array}$ & $\begin{array}{l}\text { Desperate } \\
\text { House } \\
\text { Wives }\end{array}$ & $\begin{array}{l}\text { The } \\
\text { Mentalist }\end{array}$ & $\begin{array}{l}\text { Big Bang } \\
\text { Theory }\end{array}$ \\
\hline 9 & $\begin{array}{l}\text { C.S.I.: } \\
\text { Miami }\end{array}$ & $\begin{array}{l}\text { Grey's } \\
\text { Anathomy }\end{array}$ & $\begin{array}{l}\text { C.S.I.: } \\
\text { Miami }\end{array}$ & $\begin{array}{l}\text { Desperate } \\
\text { House } \\
\text { Wives }\end{array}$ & $\begin{array}{l}\text { Sunday } \\
\text { Night } \\
\text { Football }\end{array}$ & $\begin{array}{l}\text { Desperate } \\
\text { House } \\
\text { Wives }\end{array}$ & $\begin{array}{l}\text { Gray's } \\
\text { Anathomy }\end{array}$ & $\begin{array}{l}\text { Criminal } \\
\text { Minds }\end{array}$ & The Voice \\
\hline 10 & $\begin{array}{l}\text { Everybody } \\
\text { Loves } \\
\text { Raymond }\end{array}$ & $\begin{array}{l}\text { Everybody } \\
\text { Loves } \\
\text { Raymond }\end{array}$ & House & $\begin{array}{l}\text { C.S.I.: } \\
\text { Miami }\end{array}$ & $\begin{array}{l}\text { Survivor: } \\
\text { China }\end{array}$ & $\begin{array}{l}\text { Two and a } \\
\text { Half Men }\end{array}$ & House & C.S.I. & $\begin{array}{l}\text { Two and a } \\
\text { Half Men }\end{array}$ \\
\hline
\end{tabular}

Source: Newsok, (2003-2010); The Bert Show (2010-2011); Shows.com (2011-2012)

Such phenomenon relates not only to reality shows that have young protagonists. As noted by Jean Baudrillard (2010) in his latest publication, The Agony of Power, there is a close correlation between infantilism and reality shows in general. The banality of reality shows, according to the French sociologist, is an expression of one's self as the ultimate form of confession mentioned by Foucault and coincides to the imprescriptible desire not to be anything and to be looked at as such. This is a propensity to disappearance that manifests in two ways: by demanding not to be seen or by falling into the irrational exhibitionism of one's own nothingness.

Another television sector in which the infantilization phenomenon is obvious is cartoons. In 2004, Mars Otc conducted a massive survey on the use of television by adults in which revealed interesting data: over a third of interviewees, aged between 18 and 54 years, in the last seven days had watched afternoon cartoons (either alone or with peers, never with children or grandchildren), mostly directed to a younger audience.

Furthermore, the schedule of the most prominent broadcasters has gradually adopted numerous animated series that can be appreciated by both young and older people. After the Simpsons came the Rugrats, then Futurama, and finally South Park, Family Guy and American Dad: animated sitcoms specifically aimed at an adult audience. One can also find the Japanese Anime series that, because of the extremely mature content, are broadcast only late at night.

The phenomenon, however, does not concern exclusively reality shows and animated series, but also documentaries, topical talk shows and, most of all, newscasts. From an aesthetic point of view, the image dominates the news: it has been proven that what is searched in a news anchor is not so much the facial expression or journalistic 
skills, but the fact that the viewer likes his aesthetic presence. Twenty years ago, Postman (1994: 104) sustained that what is essential is "that the viewers like looking at their faces. It is the teller, not what is told that matters here".

Not only the anchor: the image has far-back taken over the word in the newscasts themselves. Additionally, with the advent of YouTube and the exponential growth of amateur video possibilities, the newscasts seem to be pursuing the visual spectacle of the news more than its real importance.

The news has moved to second place as the content refers more and more to the color and crime. Another phenomenon that has been growing is the loss of complexity in the news in favor of variety. According to a study conducted by Louis Menand in 2002, a news program of about thirty minutes relates, on average, fifteen to twenty stories. The speed with which a topic is discussed, and with which one topic follows another, desensitizes the viewer and cancels the critical thinking skills necessary to understand and reflect on a particular story. The events in the news disregard any historical continuity or any other context: they are nothing more than fragments of reality in rapid succession, funneled in a uniform flow. They are completely idiosyncratic, do not allow assessments, and tell an irrelevant story; their aesthetic prevails over the content. In other words, although they are mainly aimed at an adult audience, the methodology with which they are built is purely infantilizing.

In the film industry, the infantilization phenomenon is particularly evident. On the one hand, in the last few years the production of kidult-movies has increased greatly, as have films that highlight the immaturity of adults male for the most part - or emphasize their inability to take responsibility and their propensity to constantly look to their past. On the other hand, we have the success of sequels, prequels and remakes of movies of the past, in which aged actors play the role of the young or that, referring to films that have shaped the history of cinema in the " $80 \mathrm{~s}$ and ' 90 s, rely on the nostalgia of the viewer. This is itself a psychological regression to earlier life stages. In summary, the major Hollywood strategy to face the motion picture crisis of recent decades has been to produce fun, hip and prosaic block-busters with simple plots and minimal dialogues, apparently addressed to a young audience, but that can be easily appreciated by adults as well.

These trends can be clearly seen in Table 2, which lists the top box office movies of the last ten years.

Table 2. Top box-office movies worldwide

\begin{tabular}{|c|c|c|c|c|c|c|c|c|c|c|}
\hline & 2003 & 2004 & 2005 & 2006 & 2007 & 2008 & 2009 & 2010 & 2011 & 2012 \\
\hline 1 & $\begin{array}{l}\text { The Lord } \\
\text { of the } \\
\text { Rings } 3\end{array}$ & Shrek 2 & $\begin{array}{l}\text { Star Wars } \\
\text { ep. } 3\end{array}$ & $\begin{array}{l}\text { Pirates } \\
\text { of the } \\
\text { Carib. } 2\end{array}$ & $\begin{array}{l}\text { Spider- } \\
\text { man } 3\end{array}$ & $\begin{array}{l}\text { The Dark } \\
\text { Knight }\end{array}$ & Avatar & $\begin{array}{l}\text { Toy Story } \\
3\end{array}$ & $\begin{array}{l}\text { Harry } \\
\text { Potter } 8\end{array}$ & $\begin{array}{l}\text { Marvel's } \\
\text { Avengers }\end{array}$ \\
\hline 2 & $\begin{array}{l}\text { Finding } \\
\text { Nemo }\end{array}$ & $\begin{array}{l}\text { Spider- } \\
\text { man } 2\end{array}$ & $\begin{array}{l}\text { Chronicles } \\
\text { of } \\
\text { Narnia }\end{array}$ & $\begin{array}{l}\text { Night } \\
\text { at the } \\
\text { Museum }\end{array}$ & Shrek 3 & Iron Man & $\begin{array}{l}\text { Trans- } \\
\text { formers } \\
2\end{array}$ & $\begin{array}{l}\text { Alice in } \\
\text { Wonder- } \\
\text { land }\end{array}$ & $\begin{array}{l}\text { Trans- } \\
\text { formers } 2\end{array}$ & $\begin{array}{l}\text { The } \\
\text { Dark } \\
\text { Knight } 3\end{array}$ \\
\hline 3 & $\begin{array}{l}\text { Pirates of } \\
\text { the Crib. }\end{array}$ & $\begin{array}{l}\text { The } \\
\text { Passion of } \\
\text { the Christ }\end{array}$ & $\begin{array}{l}\text { Harry } \\
\text { Potter } 4\end{array}$ & Cars & $\begin{array}{l}\text { Trans- } \\
\text { formers }\end{array}$ & $\begin{array}{l}\text { Indiana } \\
\text { Jones } 4\end{array}$ & $\begin{array}{l}\text { Harry } \\
\text { Potter } 6\end{array}$ & $\begin{array}{l}\text { Iron Man } \\
2\end{array}$ & $\begin{array}{l}\text { Pirates } \\
\text { of the } \\
\text { Carib. } 4\end{array}$ & $\begin{array}{l}\text { The } \\
\text { Hunger } \\
\text { Games }\end{array}$ \\
\hline 4 & $\begin{array}{l}\text { The } \\
\text { Matrix } \\
\text { Reloaded }\end{array}$ & $\begin{array}{l}\text { Harry } \\
\text { Potter } 3\end{array}$ & $\begin{array}{l}\text { War of the } \\
\text { Worlds }\end{array}$ & $\begin{array}{l}\text { X-Men: } \\
\text { the Last } \\
\text { Stand }\end{array}$ & $\begin{array}{l}\text { Pirates of } \\
\text { the Carib. } \\
3\end{array}$ & Hancock & $\begin{array}{l}\text { Twilight } \\
2\end{array}$ & Twilight 3 & $\begin{array}{l}\text { Twilight } \\
4\end{array}$ & Skyfall \\
\hline 5 & $\begin{array}{l}\text { Bruce } \\
\text { Almighty }\end{array}$ & $\begin{array}{l}\text { The } \\
\text { Incredibles }\end{array}$ & King Kong & $\begin{array}{l}\text { The Da } \\
\text { Vinci } \\
\text { Code }\end{array}$ & $\begin{array}{l}\text { Harry } \\
\text { Potter } 5\end{array}$ & Wall-E & Up & Inception & $\begin{array}{l}\text { Mission: } \\
\text { Impossib. } \\
4\end{array}$ & $\begin{array}{l}\text { The } \\
\text { Hobbit }\end{array}$ \\
\hline 6 & $\mathrm{X}$-men 2 & $\begin{array}{l}\text { The Day } \\
\text { after } \\
\text { Tomor. }\end{array}$ & $\begin{array}{l}\text { Wedding } \\
\text { Crashers }\end{array}$ & $\begin{array}{l}\text { Super- } \\
\text { man } \\
\text { Returns }\end{array}$ & $\begin{array}{l}\text { I Am } \\
\text { Legend }\end{array}$ & $\begin{array}{l}\text { Kung Fu } \\
\text { Panda }\end{array}$ & $\begin{array}{l}\text { The } \\
\text { Hang- } \\
\text { over }\end{array}$ & $\begin{array}{l}\text { Des- } \\
\text { plicable } \\
\mathrm{Me}\end{array}$ & $\begin{array}{l}\text { Kung Fu } \\
\text { Panda } 2\end{array}$ & $\begin{array}{l}\text { Twilight } \\
5\end{array}$ \\
\hline 7 & Elf & $\begin{array}{l}\text { The Bourne } \\
\text { Supremacy }\end{array}$ & $\begin{array}{l}\text { Charlie } \\
\text { and the } \\
\text { Chocol. }\end{array}$ & $\begin{array}{l}\text { Happy } \\
\text { Feet }\end{array}$ & $\begin{array}{l}\text { The } \\
\text { Bourne } \\
\text { Ultimatum }\end{array}$ & Twilight & $\begin{array}{l}\text { Star } \\
\text { Trek }\end{array}$ & Shrek 4 & Fast Five & $\begin{array}{l}\text { Spider- } \\
\text { man }\end{array}$ \\
\hline 8 & $\begin{array}{l}\text { Termi- } \\
\text { nator } 3\end{array}$ & Shrek Tale & $\begin{array}{l}\text { Batman } \\
\text { Begins }\end{array}$ & Ice Age 2 & $\begin{array}{l}\text { National } \\
\text { Treasure }\end{array}$ & $\begin{array}{l}\text { Mada- } \\
\text { gascar } 2\end{array}$ & $\begin{array}{l}\text { The } \\
\text { Blind } \\
\text { Side }\end{array}$ & $\begin{array}{l}\text { How to } \\
\text { Train Yo. }\end{array}$ & $\begin{array}{l}\text { The } \\
\text { Hang- } \\
\text { over } 2\end{array}$ & Brave \\
\hline
\end{tabular}




\begin{tabular}{|c|c|c|c|c|c|c|c|c|c|c|}
\hline 9 & $\begin{array}{l}\text { The } \\
\text { Matrix } \\
\text { Revol- } \\
\text { utions }\end{array}$ & I, Robot & $\begin{array}{l}\text { Mada- } \\
\text { gascar }\end{array}$ & $\begin{array}{l}\text { Casino } \\
\text { Royale }\end{array}$ & $\begin{array}{l}\text { Alvin } \\
\text { and the } \\
\text { Chipm. }\end{array}$ & $\begin{array}{l}\text { Quantum } \\
\text { of Solace }\end{array}$ & Alvin 2 & $\begin{array}{l}\text { The } \\
\text { Karate } \\
\text { Kid }\end{array}$ & $\begin{array}{l}\text { The } \\
\text { Smurf }\end{array}$ & Ted \\
\hline 10 & $\begin{array}{l}\text { Bad Boys } \\
2\end{array}$ & Troy & $\begin{array}{l}\text { Mr and } \\
\text { Mrs. Smith }\end{array}$ & $\begin{array}{l}\text { In } \\
\text { Pursuit } \\
\text { of } \\
\text { Happyn. }\end{array}$ & 300 & $\begin{array}{l}\text { Dr. Seuss } \\
\text { Horton }\end{array}$ & $\begin{array}{l}\text { Sherlock } \\
\text { Holmes }\end{array}$ & $\begin{array}{l}\text { Clash of } \\
\text { the Titans }\end{array}$ & Cars 2 & $\begin{array}{l}\text { Mada- } \\
\text { gascar } 3\end{array}$ \\
\hline
\end{tabular}

Source: The Movie Times, 2003-2009; Box Office Mojo (2010-2012)

Classifying these movies by genre we find that, out of a total of 100 feature films, 31 are fantasy films originally directed at children and adolescents (e.g., the Harry Potter and Pirates of the Caribbean sagas), 23 are animated movies (mostly by Pixar, such as the various Shrek and Madagascar films), 13 are films with Marvel heroes as protagonists (Batman, Spiderman, etc.), 9 are teenage comedies (such as the Twilight saga ) and 4 are kidult movies (Ted, The Hangover, etc.). What remain are just 20 films, one-fifth of the total, which are not formally addressed to young people or whose plot is not centered on the immaturity of adults

Another significant fact is that as many as 47 films out of 100 are sequels, prequels or remakes. Beyond the obvious reasons related to marketing strategies, such film typologies might be meant to satisfy the puerile and dull propensity of a public that does not want to be surprised or shocked: an audience that, as Barber (2007: 25) recently stated, just like a child seems to ask of movies and theater: "Tell me the story again, please? Now please tell me again."

Another purpose of prequels, sequels, remakes and, also, kidult movies, is to appeal on the nostalgia effect that lies in the postmodern individual who generally lives with the dimensions of uncertainty and insecurity. By reexperiencing past feelings and, therefore, regressing to previous life stages, he will find a stability that is apparently absent in the contemporary context that surrounds him. De facto, as shown by Gary Cross (2008), when people find an accelerating rate of change in many things so frustrating and alienating, they try to capture the fleeting past in their ephemeral culture and goods. It may seem strange that we seek stability in what lasted only briefly when we were young, but, as we age, our experiences as children and teens seem to be timeless.

The Internet is the dimension in which, probably, may be encountered the most striking signs of how the infantilization phenomenon took root in recent times. Table 3 shows the top ten Google searches over the past ten years.

Table 3. Most searched keywords in Google worldwide

\begin{tabular}{|c|c|c|c|c|c|c|c|c|c|c|}
\hline & 2003 & 2004 & 2005 & 2006 & 2007 & 2008 & 2009 & 2010 & 2011 & 2012 \\
\hline 1 & $\begin{array}{l}\text { Britney } \\
\text { Spears }\end{array}$ & $\begin{array}{l}\text { Britney } \\
\text { Spears }\end{array}$ & $\begin{array}{l}\text { Janet } \\
\text { Jackson }\end{array}$ & Bebo & iPhone & $\begin{array}{l}\text { Sarah } \\
\text { Palin }\end{array}$ & $\begin{array}{l}\text { Michael } \\
\text { Jackson }\end{array}$ & $\begin{array}{l}\text { Chat- } \\
\text { roulette }\end{array}$ & $\begin{array}{l}\text { Rebecca } \\
\text { Black }\end{array}$ & $\begin{array}{l}\text { Whitney } \\
\text { Houston }\end{array}$ \\
\hline 2 & $\begin{array}{l}\text { Harry } \\
\text { Potter }\end{array}$ & $\begin{array}{l}\text { Paris } \\
\text { Hilton }\end{array}$ & $\begin{array}{l}\text { Hurri- } \\
\text { cane } \\
\text { Katrina }\end{array}$ & $\begin{array}{l}\text { My- } \\
\text { space }\end{array}$ & Badoo & $\begin{array}{l}\text { Beijing } \\
2008\end{array}$ & $\begin{array}{l}\text { Face- } \\
\text { book }\end{array}$ & iPad & Google+ & $\begin{array}{l}\text { Gang-nam } \\
\text { Style }\end{array}$ \\
\hline 3 & Matrix & $\begin{array}{l}\text { Chris- } \\
\text { tina } \\
\text { Aguilera }\end{array}$ & Tsunami & $\begin{array}{l}\text { World } \\
\text { Cup }\end{array}$ & $\begin{array}{l}\text { Face- } \\
\text { book }\end{array}$ & $\begin{array}{l}\text { Face- } \\
\text { book } \\
\text { login }\end{array}$ & Tuenti & $\begin{array}{l}\text { Justin } \\
\text { Bieber }\end{array}$ & $\begin{array}{l}\text { Ryan } \\
\text { Dunn }\end{array}$ & $\begin{array}{l}\text { Hurri-cane } \\
\text { Sandy }\end{array}$ \\
\hline 4 & Shakira & $\begin{array}{l}\text { Pamela } \\
\text { Ander- } \\
\text { son }\end{array}$ & $\begin{array}{l}\text { Xbox } \\
360\end{array}$ & $\begin{array}{l}\text { Meta- } \\
\text { cafe }\end{array}$ & $\begin{array}{l}\text { Daily- } \\
\text { motion }\end{array}$ & Tuenti & Twitter & $\begin{array}{l}\text { Nicki } \\
\text { Minaj }\end{array}$ & $\begin{array}{l}\text { Casey } \\
\text { Anthony }\end{array}$ & iPad 3 \\
\hline 5 & $\begin{array}{l}\text { David } \\
\text { Beckham }\end{array}$ & Chat & $\begin{array}{l}\text { Brad } \\
\text { Pitt }\end{array}$ & $\begin{array}{l}\text { Radio- } \\
\text { blog }\end{array}$ & Webkinz & $\begin{array}{l}\text { Heath } \\
\text { Ledger }\end{array}$ & Sanalika & Friv & $\begin{array}{l}\text { Battle- } \\
\text { field } 3\end{array}$ & Diablo 3 \\
\hline 6 & 50 Cent & Games & $\begin{array}{l}\text { Michael } \\
\text { Jackson }\end{array}$ & $\begin{array}{l}\text { Wiki- } \\
\text { pedia }\end{array}$ & Youtube & Obama & $\begin{array}{l}\text { New } \\
\text { Moon }\end{array}$ & Myxer & iPhone 5 & $\begin{array}{l}\text { One } \\
\text { Direction }\end{array}$ \\
\hline
\end{tabular}




\begin{tabular}{|l|l|l|l|l|l|l|l|l|l|l|}
\hline 7 & Iraq & $\begin{array}{l}\text { Carmen } \\
\text { Electra }\end{array}$ & $\begin{array}{l}\text { Ameri- } \\
\text { can Idol }\end{array}$ & Video & Ebuddy & $\begin{array}{l}\text { Nasza } \\
\text { Klasa }\end{array}$ & $\begin{array}{l}\text { Lady } \\
\text { Gaga }\end{array}$ & $\begin{array}{l}\text { Katy } \\
\text { Perry }\end{array}$ & Adele & $\begin{array}{l}\text { Selena } \\
\text { Gomez }\end{array}$ \\
\hline 8 & $\begin{array}{l}\text { Lords of } \\
\text { the Rings }\end{array}$ & $\begin{array}{l}\text { Orlando } \\
\text { Bloom }\end{array}$ & $\begin{array}{l}\text { Britney } \\
\text { Spears }\end{array}$ & Rebelde & $\begin{array}{l}\text { Second } \\
\text { life }\end{array}$ & $\begin{array}{l}\text { Wer } \\
\text { Kennt } \\
\text { wen }\end{array}$ & $\begin{array}{l}\text { Win- } \\
\text { dows 7 }\end{array}$ & Twitter & TEPCO & iPhone 5 \\
\hline 9 & $\begin{array}{l}\text { Kobe } \\
\text { Bryant }\end{array}$ & $\begin{array}{l}\text { Harry } \\
\text { Potter }\end{array}$ & $\begin{array}{l}\text { Ange- } \\
\text { lina } \\
\text { Jolie }\end{array}$ & $\begin{array}{l}\text { Mini- } \\
\text { nova }\end{array}$ & Hi5 & $\begin{array}{l}\text { Euro } \\
2008\end{array}$ & $\begin{array}{l}\text { Dantri. } \\
\text { com.vn }\end{array}$ & Gamezer & Steve Jobs & Megan Fox \\
\hline 10 & $\begin{array}{l}\text { Tour de } \\
\text { France }\end{array}$ & Mp3 & $\begin{array}{l}\text { Harry } \\
\text { Potter }\end{array}$ & Wiki & $\begin{array}{l}\text { Club } \\
\text { Penguin }\end{array}$ & $\begin{array}{l}\text { Jonas } \\
\text { Brothers }\end{array}$ & $\begin{array}{l}\text { Torpedo } \\
\text { Gratis }\end{array}$ & $\begin{array}{l}\text { Face- } \\
\text { book }\end{array}$ & iPad 2 & $\begin{array}{l}\text { Justin } \\
\text { Bieber }\end{array}$ \\
\hline
\end{tabular}

Source: Zeitgeist, 2003-2012

It is immediately evident that most of them focus on famous celebrity teenagers (Britney Spears, Rebecca Black, Justin Bieber, etc.), the protagonists of teen movies and animated series (e.g., Harry Potter), video games (Battlefield 3, Diablo 3, etc.) and social networks (Facebook, Twitter, etc.). Out of 100 searches only 9 refer to topics which could be related to a purely adult imagination: 4 refer to media events (Iraq, Tsunami, etc.), 2 to politicians (Sarah Palin, Barack Obama), 2 to encyclopedias (Wiki, Wikipedia), and 1 to an operating system.

One might argue that the Internet is mostly used by children and young people, but that would be an incorrect statement: in a large research in $2010, \mathrm{CNN}$ proved that the average age of those who surf the Internet every day is about 36 years old. In the same study another significant fact has been shown: the majority of adults use the Internet both for professional and for recreational reasons, especially through social networks and online communities.

Social networking, therefore, initially a prerogative of the youth, over time, seems to have become very popular among adults. In 2012, 55\% of Twitter users were over 35 years old, a percentage that rises to 65\% in Facebook and to $79 \%$ in LinkedIn. Fifty-three percent of registered users in the 24 most popular social networks and online communities are over 35 years old, $28 \%$ are over 45 years old. The average age of those who use social networks is 37 years: the average user of LinkedIn is 44.2 years old, of Twitter 37.3, of Facebook 40.5.

In 2011, the research agency Ipsos MediaCT conducted a major study on behalf of the Entertainment Software Association (ESA), the largest trade association for the video game industry in the world. The survey, designed to study the makeup of the modern gamer, denied a widespread association between video games and adolescents. This survey highlighted an unexpected yet significant fact: only a quarter of those who in 2010 regularly played videogames are less than 18 years old. About half, however, are between 18 and 49 years old. The latest data recorded by ESA, in 2012, revealed that the average age of the worldwide gamer is now 37 years old. Not only that, in 1999 only $9 \%$ of those who used video games were over 50 years old; in 2012 this age group represents $26 \%$ of the market. Those ranging from 3 to 18 years old represent 25\%; we could then state that, nowadays, middle-aged people are more inclined to play video games than adolescents and teenagers.

In Die Tryin': Videogames, Masculinity, Culture, Derek Burrill (2008) connects the growing success of gaming among adults with the emergence of a new form of infantilist machismo: the boyhood phenomenon. According to the author, shooter and action video games, in which one takes control of a virile and violent avatar, allow the adult male to normalize both their childish and their macho sides. The refuge in boyhood allowed by such video games lead the adult to a new pseudo-adolescent dimension, far away from the responsibilities of maturity, to a playful and masculine parallel reality outside of time and space. Thus, video games are no longer toys for children, but technonostalgic machines that allow a regression of the male in a utopian world of fantasy and virility and an escape from a womanish reality characterized by family duties and social responsibilities. The thesis is intriguing; it is not, however, a purely male phenomenon: in 2012, $40 \%$ of all gamers in the world were women.

Shifting from a socio-psychological point of view to a socioeconomic one, we know that the worldwide video game market has grown by over 10 percentage points in the last ten years, while, during the same period, the Western economy was growing at a rate of less than $2 \%$. It is undeniable that such growth is due, at least in part, to the expansion of the target towards the adult world. Are we then dealing with another clue of the infantilization of the media? De facto, the gaming market has diversified its production, creating a segment of video games specifically addressed to adults. The ESA research cited above, however, shows another significant fact: only $17 \%$ of the games sold in 2010 worldwide were explicitly directed at an adult audience. This means that the majority of adults does 
not necessarily and exclusively enjoy games of a mature content, but prefers escapist, childish and fun games. In short, they still prefer Super Mario and Sonic the Hedgehog to interactive psychological dramas such as L. A. Noir. Therefore, has the market been gradually addressed to adults or, conversely, have adults decided to pursue a market that should not belong to them?

There is a double interpretation of the phenomenon. At a general level, postmodern society itself has gradually abandoned the idea that getting older means setting aside one's playfulness; a trend that, in most cases, has led the adult to maintain a durable coexistence with his inner child. At a more specific level, however, it is the video game market itself that has grown along with those children it was targeting in the '70s and '80s. Video games have evolved and grown along with their audiences: those who began, as children or adolescents, with the Atari 2600 and the NES have continued to use video games as the technology matured in tandem with them. It is the so-called digital generation (Prensky 2001): those who are in their thirties today have grown up with technology and developed a peculiar taste for it. They witnessed firsthand the evolution and the maturation of video games - but also of the Internet and media in general - developing a paradigm for which games should not be a prerogative of adolescence, but a diversion that is free from age limits. Previous and later generations, however, could not share such vision; to them the adult passion for video games, more than a generational issue, would be another indicator of postmodern immaturity.

\section{Final Considerations}

The empirical data and thesis displayed in this essay show a tendency considered undeniable and significant: the infantilization phenomenon is widely present in contemporary society and its analysis by the social sciences shall not exclude the dimensions of media and new technologies.

The thesis of the digital generation paradigm discussed above, may be a useful interpretation, though certainly not the only one. The same can be said for the thesis that we, as a society, have gradually abandoned the idea that getting older means abandoning fun.

The media promotion of attitudes that a classical paradigm of adulthood would necessarily understand as childish must be read as a further distinctive phenomenon of postmodernity. Even if certain generations would never explain it as such.

The considerations made in this essay, should integrate the impending reformulation of those models inherent to adulthood and social aging to which the social sciences, just like public opinion, seem more and more incapable of referring to.

\section{References}

Barber, B. R. 2007. Con\$umed. New York: Norton \& Company.

Baudrillard, J. 2010. The Agony of Power. Los Angeles: Semiotext.

Blatterer, H. 2007. Coming of Age in Times of Uncertainty. New York: Bergham Books.

Bonazzi, F. and Pusceddu, D. 2008. Giovani per Sempre. La Figura dell'Adulto nella Postmodernità. Milan: FrancoAngeli.

Burril, D. 2008. Die Tryin': Videogames, Masculinity, Culture. New York: Peter Lang.

Cross, G. 2008. Men to Boys. The Making of Modern Immaturity. New York: Columbia University Press.
Menand, L. 2002. American Studies. New York: Ferrar, Status and Giroux.

Mitchell, B. 2006. The Boomerang Age. Transitions to Adulthood in Families. Brunswick: Transaction Publisher.

Postman, N. 1994. The Disappearance of Childhood. New York: Vintage Books.

Prensky, M. 2001. "Digital Natives, Digital Immigrants." On the Horizon. 9(5).

Schor, J. B. 2004. Born to Buy: the Commercialized Child and the New Consumer Culture. New York: Scribner. 